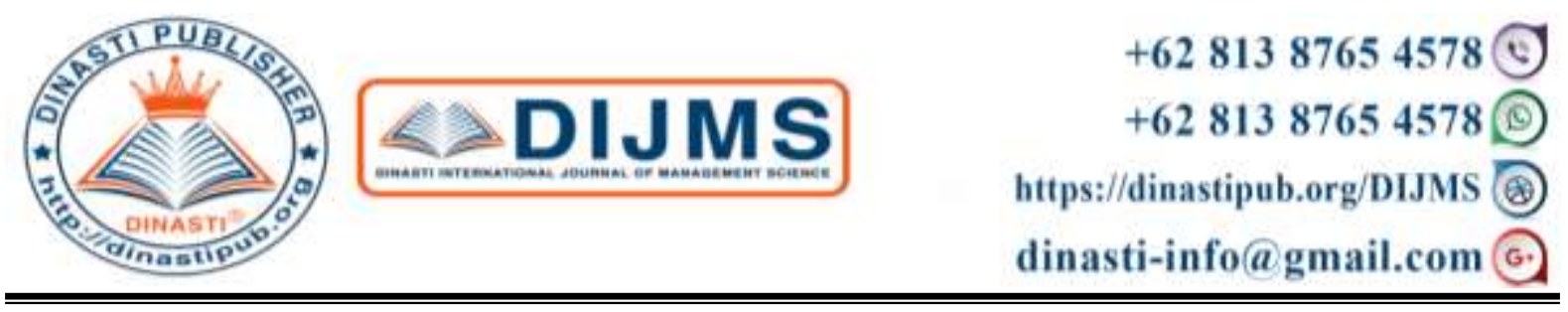

\title{
HUMAN RESOURCES INFORMATION SYSTEM TO IMPROVE EMPLOYEE PERFORMANCE
}

\section{Try Hikmawan ${ }^{1}$, Budi Santoso ${ }^{2}$}

${ }^{1)}$ Universitas Pendidikan Indonesia, Indonesia

2) Universitas Pendidikan Indonesia, Indonesia

\begin{tabular}{|c|c|}
\hline $\begin{array}{l}\text { E INFORMATION } \\
01 \text { March } 2020 \\
77 \text { March } 2020 \\
\text { March } 2020 \\
\text { y Editor) }\end{array}$ & $\begin{array}{l}\text { Abstract: Today employee performance is a } \\
\text { fundamental element for the progress of the institution. } \\
\text { Along with the changing times demanded in increasing } \\
\text { employee performance in order to achieve the } \\
\text { objectives to be achieved. The discussion of this study } \\
\text { regarding the decline in employee performance is } \\
\text { characterized by a decrease in the percentage of } \\
\text { achievement of work program targets. In this study, } \\
\text { there are two variables, namely human resources } \\
\text { information system variable (X) and employee } \\
\text { performance variable (Y). This study aims to } \\
\text { determine the effectiveness of human resources } \\
\text { information system and the level of employee } \\
\text { performance. This research method uses descriptive } \\
\text { method using the type of explanatory survey research. } \\
\text { Data collection techniques used were interviews and } \\
\text { questionnaires that used a rating scale measurement } \\
\text { scale. Data analysis techniques using simple regression } \\
\text { analysis. The population in this study is employees. } \\
\text { Based on the results of the study, showed that the } \\
\text { respondents' perceptions of performance appraisal in } \\
\text { the effective category were in the very high category. } \\
\text { Hypothesis testing shows that human resources } \\
\text { information system has a positive and significant } \\
\text { influence on employee performance } \\
\text { Keywords: Information System, Employee } \\
\text { Performance }\end{array}$ \\
\hline
\end{tabular}

\section{INTRODUCTION}

With the increasingly rapid process of information exchange in the current digital era the information technology sector has penetrated into various aspects. One that is affected by the role of information technology is the aspect of human resources. The current digital era offers to improve the performance of human resources in the organization. The success of an 
organization in the technology field depends on the support of the availability of information. Technology provides a variety of benefits that can be used to make decisions for users more interestingly (Hikmawan, Sutarni, \& Hufad, 2019). The main factors of the success of information in supporting organizational activities are data harmony and quality, data organization and procedures for their use (Turban, 2008). The low performance of human resources in the competitive era is now a major problem in an organization. Employee performance is still a concern, because performance is the core of the problems and challenges in the management of human resources of all organizations (Khan, Khan, \& Khan, 2011).

One of the services provided by implementing the human resource information system (HRIS). Human resource information system is "System used to acquire, store, manipulate, analyze, retrieve, and distribute information regarding an organization's human resources. An HRIS is not simply computer hardware and associated HR-related software. Although an HRIS includes hardware and software, it also includes people, forms, policies and procedures, and data (Michael J Kavanagh, Gueutal, \& Tannenbaum, 1990). Human resource information system (HRIS) is gigantic information system related literature including its implementation (Ball, 2001) and allows the entering, storage and manipulation of data regarding employees of a company (Khera, 2012). HRIS can support long range planning with information for labor force planning and supply and demand forecasts, staffing with information on equal employment, separations and applicant qualifications, and development with information on training program costs and trainee work performance and to manage employee database (Kadhim, Taqi, \& Shuaibu, 2012) (Bourini \& Bourini, 2011). Human Resource Information System (HRIS) implementation success has emerged as a significant challenge for organizations (Lippert \& Swiercz, 2005). The developed HRIS will help the organization to effectively store employee data more securely and accurately (Gupta, 2013). Therefore, the author has conducted research to show that there is a role for human resources information system on employee performance.

\section{LITERATURE REVIEW}

\section{Human Resources Information System}

Human Resource Information System (HRIS) is a Human Resource Management (HRM) tool that enables an organization to design and manage a comprehensive human resources strategy through information technology (Alam., 2017) (Dery, Grant, \& Wiblen, 2007). Human resources information system can be briefly defined as integrated systems used to gather, store and analyze information regarding an organization's human resources (Hendrickson, 2003). Human Resource Information System (HRIS) is a systematic way of storing data and information for each individual employee to aid planning, decision making, distribute information and submitting of returns and reports to the external agencies (Sabrina Jahan, 2014) (M J Kavanagh, Guetal, \& Tannenbaum, 1990). HRIS outline the integration between Human Resource Management (HRM) and Information Technology (Gerardine deSanctis, 1986).

In its application, HRIS can support the organization's long-term planning by utilizing staffing information (Kovach \& Cathcart, 1999). HRIS has major three quality components (Delone \& McLean, 2003) as shown in Picture 1. 


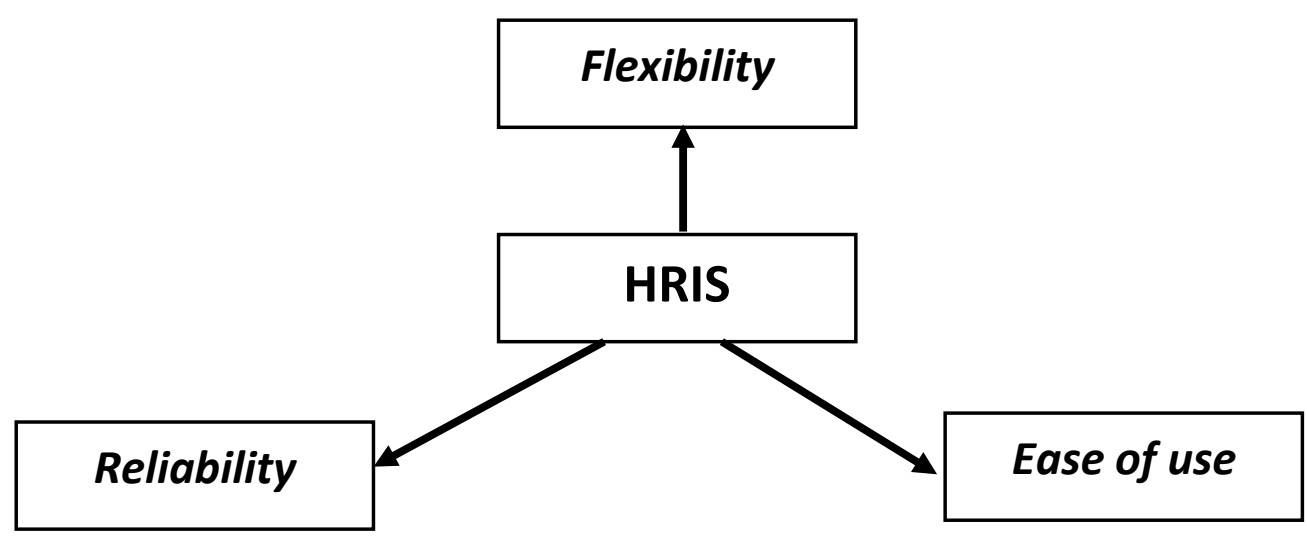

Picture 1. Quality HRIS

Source: (Delone \& McLean, 2003)

1. Flexibility

The flexibility of an information system shows that the information system applied is of good quality. The flexibility in question is the ability of information systems to make changes in relation to meeting user needs.

2. Ease of use

An information system can be said to be of quality if the system is designed to meet user satisfaction through the ease of using the information system.

3. System Reliability

Quality information systems are reliable information systems. If the system is reliable the information system is feasible to use. The reliability of information systems in this context is the resilience of information systems from damage and errors.

\section{Employee Performance}

Performance is the result of a process carried out to achieve the results achieved according to applicable measures, within a certain period of time, regarding the work and behavior and actions. Performance has a broad meaning, not only as a result of work, but also how the work process takes place (Nur, 2013). Employee performance is how much employees contribute to the company including the quantity of output, the quality of output, the time period, workplace attendance and cooperative attitude (Murti \& Srimulyani, 2013). People is one factor that cannot be duplicated or imitated by the competitors and is considered the most valuable asset if managed and engaged properly (Anitha, 2014). Employee performance is higher in happy and satisfied workers and the management find it easy to motivate high performers to attain firm targets (Kreitner, Kinicki, \& Buelens, 1999). Performance indicators is Quality of work, Promptness, Initiative, Capability, and Communication (Sedarmayanti, 2001). made:

From the overall description above, a causality model and research hypothesis can be 


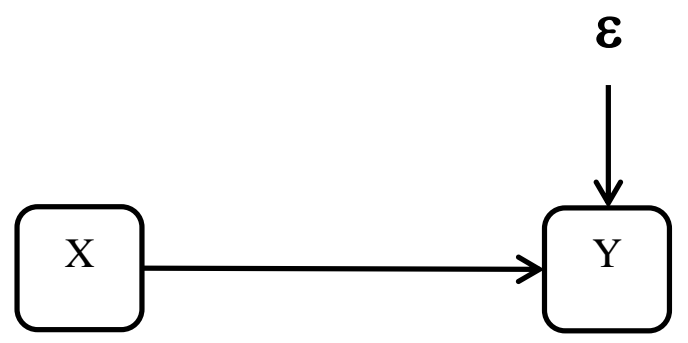

Description :

Picture 2. Variable Causality Relations Model

$\mathrm{X} \quad$ : Human Resources Information System Variable

Y : Employee Performance Variable

$\varepsilon \quad:$ Another factor that influences $\mathrm{Y}$

Hypotheses

$\mathrm{H}_{0} \quad$ = means that there was no positive influence of human resources information system on employee performance.

$\mathrm{H}_{1} \quad=$ means that there was a positive influence of human resources information system on employee performance.

\section{RESEARCH METHODS}

The research method in conducting a research is needed to direct and serve as a guideline in research activities so that with the use of appropriate methods, research objectives can be achieved (Gibson et al., 1996). The steps in a study are called research procedures or research methods. In this research method will be contained several tools and certain techniques that are used to test a research hypothesis. This research employed the explanatory survey method. The respondents were 40 employees. This research aims at seeing the picture and the influence of the role of human resources information system on employee performance. The resulting data were collected using questionnaire methods and data collection techniques through questionnaires with Likert scale. Statistical analysis techniques used for processing data were descriptive analysis techniques and inferential analysis techniques.

\section{FINDINGS AND DISCUSSION}

An information system is very influential for an agency. Because the information system is used as a pathway to get important communication as a basis for information in decision making by superiors on the work of their employees. Human resources information system aims to provide answers to overcome the problems faced by the company in improving the performance of its employees so that the performance set by the company can be achieved. The relationship between Human Resource Software Human System (X) variables and employee performance variables (Y) refers to the opinions of (Aston II Beadles, M.Lowery, \& Johns, 2005) which say that: "The result concerning Impact of Human Resource Information System is not much benefit to performance in a company due to lack of knowledge and training in the use of Human Resource Information System to its employees". 


\section{Human Resources Information System}

Indicators that exist in human resources information system were adapted to the application conditions that existed in the object of research. The human resources information system average score was 3.01. This showed that according to respondents' perceptions, human resources information system was at a moderate level. Table 1 presents the average score of each indicator that was used as a measure of human resources information system.

Table 1. Respondents' Responses Recapitulation of

Human Resources Information System Variable in Average Score (X)

\begin{tabular}{|l|c|}
\hline \multicolumn{1}{|c|}{ Indicator } & Average Score \\
\hline Flexibility & 2.89 \\
\hline Ease of Use & 3.01 \\
\hline Reliability & 3.11 \\
\hline Average & 3.01 \\
\hline
\end{tabular}

Source: Processed Data

When viewed from table 1 , shows that the average score of respondents' answers to the human resources information system variable is 3.00 .

\section{Employee Performance}

The description of employee performance was obtained by calculating indicator of employee performance that is quality of work, promptness, initiative, capability, and communication. The results of the data processing obtained the details as shown in the following table:

Table 2. Respondents' Responses Recapitulation

Employee Performance Variable in Average Score (Y)

\begin{tabular}{|l|c|}
\hline \multicolumn{1}{|c|}{ Indicator } & Average Score \\
\hline Quality of Work & 3.05 \\
\hline Promptness & 3.35 \\
\hline Initiative & 3.16 \\
\hline Capability & 2.81 \\
\hline Communication & 3.04 \\
\hline \multicolumn{2}{|c|}{ Average } \\
\hline
\end{tabular}

Source: Attached Processed Data

Seen from Table 2, the average score of the respondents' answer to the employee performance variable was 3.08 .

\section{CONCLUSION AND SUGESTION}

Based on the identification of the problem to be studied, the research objectives to be achieved, the hypothesis to be investigated, and the results of data processing and analysis, the researchers reach several conclusions as follows is the implementation of the Human Resource Information System (HRIS) has an impact on improving the performance of employees state civil apparatus. This can be seen in the recapitulation of the respondents' answers to the questionnaire distributed in general, the dominant respondents gave sufficient 
answers, agreed and strongly agreed on the ease of implementing the Human Resource Information System (HRIS), but due to lack of training for their employees, employee performance was still not optimal. So that the expected performance achievement has not reached the target set from the annual target.

Successfully confirmed the impact of the implementation of the Human Resource Information System (HRIS) on employee performance, it is recommended that the use of the Human Resource Information System (HRIS) Software be further improved and optimized so that employee performance can be further increased in accordance with performance standards.

\section{REFERENCE}

Alam., J. (2017). Human Resource Information System: a Quality Concept. International Journal of Advanced Research, 5(9), 1423-1427. https://doi.org/10.21474/ijar01/5462

Anitha, J. (2014). Determinants of employee engagement and their impact on employee performance. International Journal of Productivity and Performance Management, 63(3), 308-323. https://doi.org/10.1108/IJPPM-01-2013-0008

Aston II Beadles, N., M.Lowery, C., \& Johns, K. (2005). The Impact of Human Resource Information Systems: An Exploratory Study in the Public Sector An Exploratory Study on the Public Sector. Communications of the IIMA, 5(4), 39-46. Retrieved from http://scholarworks.lib.csusb.edu/ciima\%5Cnhttp://scholarworks.lib.csusb.edu/ciima/vol 5/iss $4 / 6$

Ball, K. S. (2001). The use of human resource information systems: a survey. Personnel Review.

Bourini, F., \& Bourini, I. (2011). Investigating the Relationship between Human Resource Information System and Strategic Capability among Employees: Jordan Case Study. Journal of Advanced Social Research, 1(1), 63-75.

Delone, W. H., \& McLean, E. R. (2003). The DeLone and McLean Model of Information Systems Success: A Ten-Year Update. Journal of Management Information Systems, 4, 9-30. https://doi.org/10.1016/j.giq.2003.08.002

Dery, K., Grant, D., \& Wiblen, S. (2007). Human Resource Information Systems (HRIS ): Replacing or Enhancing HRM. Work and Organisational Studies: The University of Sydney., (May 2014).

Gibson, C. M., Cannon, C. P., Daley, W. L., Dodge Jr, J. T., Alexander, B., Marble, S. J., ... Poole, W. K. (1996). TIMI frame count: a quantitative method of assessing coronary artery flow. Circulation, 93(5), 879-888.

Gupta, B. (2013). Human Resource Information System (HRIS): Important Element of Current Scenario. IOSR Journal of Business and Management, 13(6), 41-46. https://doi.org/10.9790/487x-1364146

Hendrickson, A. R. (2003). Human resource information systems: Backbone technology of contemporary human resources. Journal of Labor Research, 24(3), 381-394. https://doi.org/10.1007/s12122-003-1002-5

Hikmawan, T., Sutarni, N., \& Hufad, A. (2019). The role of electronic learning media in creativity learning. Journal of Physics: Conference Series, 1375(1). https://doi.org/10.1088/1742-6596/1375/1/012030

Kadhim, R., Taqi, B., \& Shuaibu, B. (2012). Prototyping A Hospital Human Resource Information System. International Journal of Independent Research and Studies, 1(1), 33-38. 
Kavanagh, M J, Guetal, H., \& Tannenbaum, S. (1990). HRIS: Development and application. Boston: PWS Kent Publishing Company.

Kavanagh, Michael J, Gueutal, H. G., \& Tannenbaum, S. I. (1990). Human resource information systems. Boston: PWS-Kent.

Khan, R. A. G., Khan, F. A., \& Khan, M. A. (2011). Impact of training and development on organizational performance. Global Journal of Management and Business Research, 11(7).

Khera, D. S. N. (2012). Human Resource Information System and its impact on Human Resource Planning: A perceptual analysis of Information Technology companies. IOSR Journal of Business and Management, 3(6), 6-13. https://doi.org/10.9790/487x-0360613

Kovach, K. A., \& Cathcart, C. E. (1999). Human Resource Information Systems (HRIS): Providing Business with Rapid Data Access, Information Exchange and Strategic Advantage. Public Personnel Management, 28(2), 275-281. https://doi.org/10.1177/009102609902800208

Kreitner, R., Kinicki, A., \& Buelens, M. (1999). Organizational behavior ". McGraw-Hill. Higher Education, First European Edition, 118.

Lippert, S. K., \& Swiercz, P. M. (2005). Human resource information systems (HRIS) and technology trust. Journal of Information Science, 31(5), 340-353. https://doi.org/10.1177/0165551505055399

Murti, H., \& Srimulyani, V. A. (2013). Pengaruh Motivasi Terhadap Kinerja Pegawai Dengan Variabel Pemediasi Kepuasaan Kerja Pada Pdam Kota Madiun. JRMA Jurnal Riset Manajemen Dan Akuntansi, 1(1), 10-17.

Nur, S. (2013). KONFLIK, STRES KERJA DAN KEPUASAN KERJA PENGARUHNYA TERHADAP KINERJA PEGAWAI PADA UNIVERSITAS KHAIRUN TERNATE. 1(3), 739-749. https://doi.org/10.1109/siu.2009.5136498

Sabrina Jahan, S. (2014). Human Resources Information System (HRIS): A Theoretical Perspective. Journal of Human Resource and Sustainability Studies, 02(02), 33-39. https://doi.org/10.4236/jhrss.2014.22004

Sedarmayanti, H. (2001). Sumber daya manusia dan produktivitas kerja. Bandung: CV Mandar Maju.

Turban, E. (2008). Information technology for management. John Wiley \& Sons, Inc. 